\title{
The Moderating Effect of Perceived Policy Effectiveness on Recycling Intention
}

\begin{abstract}
Currently, recycling is one of the main strategies to reduce the reliance on landfills in Hong Kong, where its landfills will reach their full capacities by the end of the 2010s. In this study, we surveyed 246 people in Hong Kong to examine the moderating effect of perceived policy effectiveness on recycling. According to the results, the perceived policy effectiveness negatively moderated the relationships between subjective norm and recycling intention, as well as those between consequences awareness and recycling intention. The findings provided insightful information for policy makers to shape a more effective recycling policy.
\end{abstract}

Keywords: recycling; attitude; Theory of Planned Behaviour; policy; Hong Kong

\section{Introduction}

Over the past three decades, daily municipal solid waste per capita in Hong Kong increased from $0.97 \mathrm{~kg}$ to $1.27 \mathrm{~kg}$, this implied that each people in Hong Kong produced $30 \%$ more waste (Environment Bureau, 2013). In May 2013, the Government published a blueprint for the sustainable use of resources for the coming decade. It highlighted daily domestic waste generation rate per capita in Hong Kong is the highest among other Asian cities including Taipei, Seoul and Tokyo (Environment Bureau, 2013). The document also illustrated the heavy reliance on landfills in Hong Kong where $52 \%$ of the municipal solid waste is disposed of there.

Hong Kong is a compact and land-hungry city (Ganesan and Lau, 2000; Tang et al., 2007). It has limited and scarce land resources for landfills. As the landfills will reach their full capacities by the end of the 2010 s, the Hong Kong Government proposed to expand the three current landfills from 270 hectares to 550 hectares. However, this drew criticism from both environmental groups and the residents because of the potential environmental impacts (Legislative Council, 2013). In the meantime the Government targeted to reduce the landfilling rate from $52 \%$ to $22 \%$ by incineration and recycling in ten years' time. It has also planned to mobilize the community to participate in related campaigns (Environment Bureau, 2013).

Waste reduction, reuse and recycling are becoming the key elements of waste management strategies in Hong Kong. They can help in both conserving natural resources and reducing demands for valuable landfill space (Environmental Protection Department, 2010). Among 
these elements, Chen and Tung (2010) stated that recycling becomes more popular because it can reduce waste and turn waste into usable resources.

Previous researches had examined the Theory of Planned Behaviour (TPB) (Ajzen, 1991) in explaining the factors that influence recycling behaviour (e.g., Oom Do Valle et al., 2005; Sidique et al., 2010; Tonglet et al., 2004). These studies had also drawn policy implications for changing factors influencing the behaviour. The discussion on policy measures stressed how to change attitude, address social norm and facilitate pro-environmental behaviour (Steg and Vlek, 2009). Wan and Shen (2013) proposed the relevance of perceived policy effectiveness to recycling behaviour, however the idea was not empirically tested.

The main contributions of this paper are the examinations of moderating effects of perceived policy effectiveness that explain recycling behaviour. A better understanding of the recycling intention could then be gained for policy formulation.

\section{Literature Review and Conceptual Framework}

\subsection{Prior Study on Recycling Attitude and Behaviour}

The Theory of Reasoned Action gave rise to the Theory of Planned Behaviour (TPB; Ajzen, 1991) (TRA; Ajzen and Fishbein, 1980). In aspects such as the dishonest actions of college students (Beck and Ajzen, 1991), smoking (Godin et al., 1992), driving violations (Parker et al., 1992), technology acceptance (Mathieson, 1991), and the use of public transportation (Heath and Gifford, 2002), attitude-behaviour studies have popularly made use of the TPB. The TPB established the ground for researches on recycling behavior. As a result, some researchers in this field had used the TPB in their studies (e.g., Cheung et al., 1999; Davis et al., 2006; Oom Do Valle et al., 2005; Oreg and Katz-Gerro, 2006; Sidique, et al., 2010; Tonglet et al., 2004; Wan et al., 2012). The flexibility of adding variables allowed by TPB, as mentioned by Ajzen (1991), can contribute a lot to explain certain behaviours. Lots of studies on recycling attitude and behaviour suggested adding variables to improve the sufficiency of their respective models.

TPB accounted for three main predictors of behavioural intention: Attitude refers to a function of an individual's beliefs towards a behaviour. Subjective norm (or social pressure) is the function of the perceived expectations of a person by other individuals or groups important or close to him / her (like friends, peers, neighbours), and his / her motivation to live up to these expectations. Perceived Behavioural Control (PBC) is an individual's perception of his or her capability to perform certain behaviours (Ajzen, 1991; Fishbein and 
Ajzen, 1975). These three predictors had confirmed to be the crucial predictor of recycling intention (such as Barr et al., 2001; Kelly et al., 2006; Oskamp et al., 1991; Tonglet et al., 2004; Vining and Ebreo, 1990; Sidique et al., 2010).

Awareness of consequences and moral norm can be incorporated in the study on recycling behaviour (Tonglet et al., 2004). They were proved to be significant predictors of recycling (Tonglet et al., 2004; Chen and Tung, 2010). An individual's concern with personal ethics and social responsibility when performing certain behaviour is known as his / her moral norm (Chen and Tung, 2010). The intention to perform recycling would be increased by higher awareness level of desirable consequences of certain behaviour, as explained by Davies et al. (2002).

\subsection{The Moderating Effect of Perceived Policy Effectiveness}

TPB had been proved to be a robust model in explaining pro-environmental behaviour. Previous studies had applied the model and drawn policy implications for changing factors influencing recycling behaviour (e.g. Tonglet et al., 2004; Davis et al., 2006; Chen and Tung, 2010). The discussion on policy implications commonly stressed how to change attitude, address social norm through information and communication campaign, and facilitate recycling behaviour through setting up appropriate and convenient recycling facilities.

Wan and Shen (2013) discussed the relevance of perceived policy effectiveness (PPE) and recycling behaviour. The PPE refers to an individual's favourable or unfavourable evaluation on the clarity, adequacy and facilitation of policy measures (e.g. sufficiency of waste separation bins, clarity of guidelines and promotion, etc.). It may function as more than just a direct predictor of behavior. PPE may also moderate the influence of other variables on behavior. Wan and Shen (2013) further explained that a policy measure serves as a motivational device: if one perceives a stronger and more effective motivation, the intention to perform certain behaviour will be enhanced.

Suppose an individual carries a favourable attitude towards recycling, but feels that the public authority does not facilitate such action. This individual is likely to have low intention to recycle. On the contrary, if an individual is having a weak attitude towards recycling while under effective facilitation by the public authority, he or she would still have low intention to recycle. In the field of consumer marketing, MacKenzie and Spreng (1992) proved that motivation moderates the relationship between attitude and behaviour. Since PPE serves as a motivational device, the following hypothesis is proposed. 
Hypothesis $1(\mathrm{H1})$ : $\quad$ Perceived policy effectiveness will have a positive moderating effect on the relationship between attitude and recycling intention.

The social cognitive theory developed by Bandura (1989) suggested that people's behaviour is a response to what they learn from watching others do in the context of particular physical and social environments; this highlighted the importance of subjective norm in the TPB.

In Trafimow's study (2000) in the field of health psychology, if a person has the habit to perform a certain behaviour, the link between subjective norm and behavioural intention will be weaker. We argued that subjective norm is an important predictor of recycling intentions, particularly at the introductory stage of recycling schemes. It takes time for people to learn and to gain knowledge on recycling activities. If a public authority is effectively motivating recycling behaviour, the influence of subjective norm would become weaker. The following hypothesis is therefore proposed.

Hypothesis 2(H2): $\quad$ Perceived policy effectiveness will have a negative moderating effect on the relationship between subjective norm and recycling intention.

In relation to $\mathrm{PBC}$, public recycling scheme can establish a plan to set up appropriate and convenient recycling facilities, e.g. drop-off points, curbside collection (Davis et al., 2006) to strengthen the PBC of individuals. Ajzen (1991) suggested that PBC increases an individual's motivation to perform certain behaviour, this is considered as perceived competence of performing the behaviour. $\mathrm{PBC}$ and PPE can therefore be regarded as intrinsic and extrinsic motivational factors respectively. When an individual is intrinsically motivated to perform recycling behavior (i.e. high $\mathrm{PBC}$ ), the behavioral intention would be higher. The extrinsic motivational factor (i.e. PPE) would then strengthen the link between PBC and behavioural intention. The following hypothesis is proposed.

Hypothesis 3 (H3): $\quad$ Perceived policy effectiveness will have a positive moderating effect on the relationship between $\mathrm{PBC}$ and recycling intention.

Similar to the nature of subjective norm, recycling intentions are unconsciously directed by social responsibility. The perceived moral obligation would play an important role in influencing individuals' intentions to perform recycling behaviour. This normative influence would be more important at the introductory stage of recycling schemes, the time when people would follow the perceived moral norm to perform socially desirable behaviour. When a public authority effectively and adequately motivates and facilitates recycling behaviour, the influence of moral norm on recycling intentions would become weaker. The 
following hypothesis is proposed.

Hypothesis 4 (H4): $\quad$ Perceived policy effectiveness will have a negative moderating effect on the relationship between moral norm and recycling intention.

Bamberg and Schmidt (2003) stressed that individuals would select an alternative with the most positive behavioural consequences. If an individual has a higher level of awareness of the positive consequences for certain behaviour, the intention to perform such behaviour would be higher. Fiske et al. (1994) suggested in their study in consumer behaviour that the relationship between consumer knowledge and behaviour depends on the market environment. This proposes the knowledge-behaviour link is moderated by external factors.

In the context of recycling, when a public authority is effectively motivates such behaviour, the intention to perform requires explicit attention on the consequences of recycling. Finally the following hypothesis is proposed.

Hypothesis 5 (H5): $\quad$ Perceived policy effectiveness will have a negative moderating effect on the relationship between consequence awareness and recycling intention.

Drawing upon the aforementioned literature, a conceptual framework is formulated in Figure 1 . 


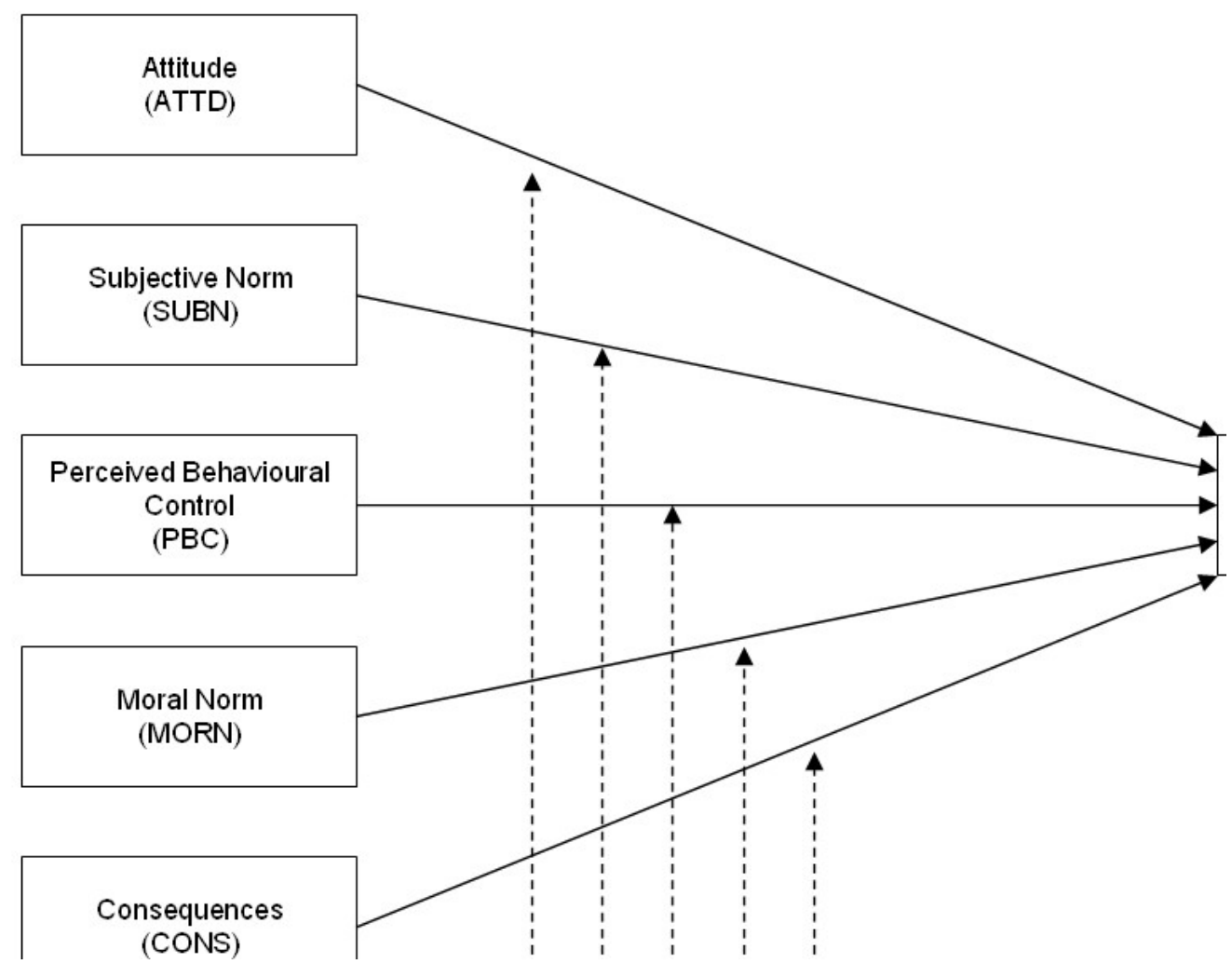

Figure 1 The Conceptual Framework

\section{Questionnaire Design and Data Collection}

In this study, the questionnaire used was compiled according to some recycling literature and the TPB theoretical framework (Ajzen, 1991; Tonglet et al., 2004; Sidique et al., 2010).

- The new constructs' indicators for perceived policy effectiveness were based on the current policy measures in Hong Kong (Environmental Protection Department, 2005, 2010) (see Appendix A).

- A seven-point Likert scale (with 7 indicating a positive view and 1 a negative view) was used to measure the components of the proposed model.

- The questionnaire contained items of the six major independent variables: attitude, subjective norm, PBC, moral norm, awareness of consequences and perceived effectiveness of government policy.

- It also had questions regarding the dependent variable of recycling intention, and questions requesting demographic information (such as age, gender, education level and monthly income).

Twenty copies of the questionnaire were randomly distributed in a pilot test to enhance the 
study's validity. The test results were used to refine some wordings on the questionnaire; this then became the final version.

Four shopping malls and two railway stations, covering 3 major regions in Hong Kong, were chosen where the street survey was conducted:

- The malls were selected based on a study on shopping mall's tenant mix by Yiu and Xu (2012); these malls were readily accessible by public transportation.

- One railway station is located in a residential area with the highest population in Hong Kong (Census and Statistics Department, 2011), while another is one of the busiest stations (Information Services Department, 2012) in a commercial area.

246 responses were collected, and the respondents' profiles are detailed in Table 1.

Table 1 Respondent Profile

\begin{tabular}{|c|c|c|}
\hline Demographic Variable & $\mathbf{N}$ & Percentage \\
\hline \multicolumn{3}{|l|}{ Gender } \\
\hline Female & 131 & $53.25 \%$ \\
\hline Male & 115 & $46.75 \%$ \\
\hline \multicolumn{3}{|l|}{ Age } \\
\hline Under 20 & 9 & $3.66 \%$ \\
\hline $20-24$ & 83 & $33.74 \%$ \\
\hline $25-29$ & 50 & $20.33 \%$ \\
\hline $30-34$ & 48 & $19.51 \%$ \\
\hline $35-39$ & 10 & $4.07 \%$ \\
\hline $40-44$ & 12 & $4.88 \%$ \\
\hline $45-49$ & 17 & $6.91 \%$ \\
\hline 50 or above & 17 & $6.91 \%$ \\
\hline \multicolumn{3}{|l|}{ Education Level } \\
\hline Primary & 22 & $8.94 \%$ \\
\hline Lower Secondary & 9 & $3.66 \%$ \\
\hline Upper Secondary & 71 & $28.86 \%$ \\
\hline Sub-degree & 44 & $17.89 \%$ \\
\hline Bachelor's Degree & 89 & $36.18 \%$ \\
\hline Master's Degree or above & 11 & $4.47 \%$ \\
\hline \multicolumn{3}{|l|}{ Monthly Income (HK\$) } \\
\hline Below 9999 & 95 & $38.62 \%$ \\
\hline $10,000-19,999$ & 92 & $37.40 \%$ \\
\hline $20,000-29,999$ & 31 & $12.60 \%$ \\
\hline
\end{tabular}




\begin{tabular}{lcl}
\hline $30,000-39,999$ & 20 & $8.13 \%$ \\
$40,000-49,999$ & 4 & $1.63 \%$ \\
Above 50,000 & 4 & $1.63 \%$ \\
\hline
\end{tabular}

\section{Data Analysis}

Structural Equation Modeling (SEM) can be used to assess latent, unobserved concepts containing multiple observed indicators (Chin, 1998b; Jöreskog, 1989). Partial Least Squares (PLS) is a common statistical approach to SEM; it can be used to confirm the validity of constructs of an instrument, and assess the structural relationships among those constructs (Chin, 1998a; Gefen et al., 2000). PLS requires a less strict adherence to distributional assumptions which is more suitable for theory development compared with covariance-based structural equation modeling (Jöreskog and Wold, 1982). As the PLS' premises were less limiting, and the sample size required was relatively small, this study adopted PLS. "SmartPLS 2.0" (Ringle et al., 2005), a statistical software application for PLS-based path modeling, was used to measure the causal model.

\subsection{Measurement model}

The study examined the convergent and discriminant validity of indicators, as well as the composite reliability of indicators to assess the PLS measurement model. Through examining the factor loadings and construct scores computed in PLS, the convergent validity tested the relationships among the indicators within the same construct. The following criteria served as the base to evaluate the measurement scales (Fornell and Larcker, 1981; Chin, 1998b):

(1) All indicator factor loadings should be considerable and larger than 0.5 .

(2) Composite reliability should be larger than 0.7 .

(3) Average variance extracted (AVE) by each construct should be larger than 0.5 .

All the standard factor-loading values in the confirmatory factor analysis of the measurement model were significant at $\mathrm{p}=0.01$, and larger than 0.5 . The composite reliabilities and the AVE of constructs met the criteria for convergent validity above. In addition, a rule for assessing discriminant validity requires the square root of the AVE to be larger than the correlations between the construct and any other one in the model (Chin, 1998b). All constructs fulfilled this condition. 


\subsection{Structural model}

The structural model was evaluated by examining the structural paths, t-statistics, and variance explained (i.e., $\mathrm{R}^{2}$ value). Path significances were determined by running the model using a bootstrap resampling routine with 246 cases and 1,000 samples. This is a nonparametric method to assess the significance level of partial least square estimates (Chin, 1998b) in which sub-samples are generated by randomly choosing a case from the data set. Hypothesis tests were carried out to test the study's proposed model. Table 2 summarizes the results of the main and moderating effects in the analysis.

Table 2 Testing Results of the Main Effects and Moderating Effects of Recycling Intention.

\begin{tabular}{|c|c|c|c|c|c|c|}
\hline Constructs & $\beta$ & $\begin{array}{c}\text { Model } 1 \\
\text { t-value }\end{array}$ & Sig. & $\beta$ & $\begin{array}{c}\text { Model } 2 \\
\text { t-value }\end{array}$ & Sig \\
\hline ATTD & 0.04 & 0.59 & & -0.13 & 0.60 & \\
\hline SUBN & 0.06 & 1.42 & & 0.31 & 2.17 & * \\
\hline $\mathrm{PBC}$ & 0.30 & 5.63 & $* *$ & 0.50 & 2.57 & * \\
\hline MORN & 0.34 & 5.27 & $* *$ & 0.29 & 1.22 & \\
\hline CONS & 0.02 & 0.30 & & 0.41 & 2.24 & $*$ \\
\hline POLICY & 0.28 & 6.38 & $* *$ & 0.92 & 6.44 & ** \\
\hline ATTD x POLICY & & & & 0.33 & 0.84 & \\
\hline SUBN x POLICY & & & & -0.39 & 2.00 & * \\
\hline PBC x POLICY & & & & -0.28 & 0.95 & \\
\hline MORN x POLICY & & & & 0.02 & 0.05 & \\
\hline CONS $x$ POLICY & & & & -0.83 & 2.25 & $*$ \\
\hline $\mathrm{R}^{2}$ & & 0.81 & & & 0.83 & \\
\hline$f^{2}$ & & & & & 0.12 & \\
\hline
\end{tabular}

$* p<0.05, * * p<0.01$

Hair, et al. (2011) proposed that $\mathrm{R}^{2}$ values of $0.25,0.50$ and 0.75 in the structural model of PLS can be interpreted as weak, moderate and substantial respectively. All the four models shows substantial amount of variance $\left(\mathrm{R}^{2}\right.$ values ranged from 0.74 to 0.83$)$ in recycling intention that can be explained by the proposed predictors included. Cohen (1988) proposed that the effect of a latent predictor can be calculated using the formula $\mathrm{f}^{2}=\left(\mathrm{R}^{2}\right.$ incl $\left.-\mathrm{R}^{2}{ }_{\text {excl }}\right) /(1$ $-\mathrm{R}^{2}$ incl); and the values $0.02,0.15$, and 0.35 could be interpreted as small, medium, or large effect at the structural level respectively.

The main effects of perceived policy effectiveness should be included in the consumers' recycling intention equation as an independent variable. This tested whether this potential moderator influences the recycling intention before testing the moderating effect. Model 1 accounted for $81 \%$ of variance in recycling intention that could be explained by $\operatorname{PBC}(\beta=$ $0.30, p<0.01)$, moral norm $(\beta=0.34, p<0.01)$ and perceived policy effectiveness $(\beta=0.28$, $p<0.01)$. Model 2 accounted for $83 \%$ of variance in recycling intention after the moderator 
of the perceived policy effectiveness was included. The value of the effect $\left(\mathrm{f}^{2}\right)$ for the moderating links was 0.12 which represented a small to medium effect; but two significant moderating path, SUBN $x$ POLICY to INT and CONS x POLICY to INT indicated strong beta values of -0.39 and -0.83 respectively. The results showed that $\mathrm{H} 2$ and $\mathrm{H} 5$ were supporter (but not H1, H3 and H4). The perceived policy effectiveness had negative moderating effect on the link between subjective norm and recycling intention, with a path coefficient of -0.39 , and a t-value of 2.00 . This implied that the effect of subjective norm on recycling intention would decrease with any increase in perceived policy effectiveness. In addition, the link between consequences awareness and recycling intention was negatively moderated by perceived policy effectiveness, with a path coefficient of -0.83 , and a t-value of 2.25. This means when an individual perceives a high degree of policy effectiveness, the positive relationship between consequences awareness and recycling intention would diminish.

PLS does not provide various validations of model such as $\chi^{2}$ and other related measures like covariance-based structural equation modeling does (Henseler and Sarstedt, 2013). However, a criterion of goodness of fit (GoF) for PLS was proposed as geometric mean of the average communality and the average $\mathrm{R}^{2}$ by Tenenhaus et al. (2004). GoF is defined as small (0.35), medium (0.50) and large (0.61) (Latan and Ghozali, 2012). The model in this study had a GoF value of 0.82 ; this indicated that the model was good fit.

\section{Discussion}

Two of the five moderating effects (i.e. subjective norm and perceived policy effectiveness; consequences awareness and perceived policy effectiveness) were significant. The coefficients of the two interaction terms were negatively significant. This meant strong subjective norms and consequences awareness were associated with a stronger intention to recycle, especially when the perceived policy effectiveness was considered to be weak.

The possible explanation is that if a government designs and implements effective policy measures to encourage and facilitate recycling, the social influence and awareness of the positive consequences of recycling would become less important. This is because when an individual is strongly motivated by policy measures (e.g. information and persuasion, recycling facilities), the impact of his / her social groups and whether he / she is aware of the consequences would have a lower impact on the recycling intention.

\subsection{Policy Implications}


These findings revealed the key challenges and considerations for policy makers about the design and implementation of recycling policy. Social norm and awareness of consequences would become less important when the perceived policy effectiveness is high. Therefore, it may not be necessary to promote recycling behaviour as a social trend and stress the positive consequences of recycling when recycling has become a widely adopted behaviour. Wan and Shen (2013) summarizes a few approaches in enhancing the perceived effectiveness of public policy.

Kingdon (1995, p.201) proposed that policy window is "an opportunity for advocates of proposals to push their solutions, or to push attention to their special problems". The strength of public sentiments can lead to the opening of a policy window. For example, the Hong Kong Government proposed in June 2013 to double the size of the three current landfills from 270 hectares to 550 hectares (Legislative Council, 2013), and this drew criticism from the society. Repeated media exposures of the negative environmental impacts resulted in protests and strong politicians' opposition. This would be an appropriate time to put forward a basket of policy measures to encourage and facilitate recycling behaviour.

Public participation would also increase the policy's sense of "ownership". If sufficient participation or opinion is collected during the stage of policy design, the perceived effectiveness of the policy can be enhanced. Geller (2002) mentioned that rewards' association with positive attitude makes it more effective than punishments. What is more, rewards should be pleasant enough for the public to change their behaviours. In the context of recycling behaviour, the proposed waste charging in Hong Kong (Environmental Bureau, 2012) may be interpreted as a punishment because additional charges are imposed on households. The government should carefully design the communication strategies to positively project the nature of the fee.

Steg and Vlek (2009) concluded that an effective communication program can enhance the public's perception of the policy effectiveness. Promotions can accent what the Government has been doing to facilitate and encourage recycling, what accomplishments have been achieved so far, and the subsequent positive impacts on the environment.

\subsection{Limitations and Future Research}

This study contained several limitations that should be addressed in future research:

- A rather apparent limitation is its relatively small sample taken from Hong Kong.

- The local policy measures on waste reduction and recycling can have unique characteristics. 
- Although a street survey was conducted that was intended to cover a wider population, the groups aged below 30 were over-represented in the sample. This calls for research efforts to verify the results for other samples.

Thus, the findings of the study may or may not be generalized in other areas and contexts. Further research is necessary to apply the model in different settings and with different groups, and consider proving the linkages between expectation and attitude. It should also be noted that policy measures are considered a single construct in this study. The correlation between each category of the policy tools and recycling intention should be further investigated. Lastly, it would be interesting to consider comparative studies to unearth a more in-depth understanding of perceived policy effectiveness and recycling intention in different contexts, and to better generalize the results.

\section{Conclusions}

This study attempted to explain the moderating effect of perceived policy effectiveness. The results showed that perceived policy effectiveness negatively moderated the positive relationships between subjective norm and recycling intention, as well as those between consequences awareness and recycling intention. While previous researchers have extended the TPB with additional constructs for recycling behaviour, this study filled the gaps in the literature by incorporating perceived policy effectiveness into the empirical research model. The enhanced model helped policy makers better understand the factors affecting recycling intention. 


\section{References}

Ajzen, I. (1991). The Theory of Planned Behaviour. Organizational Behaviour and Human Decision Processes, 50, 170-211.

Ajzen, I., and Fishbein, M. (1980). Understanding attitude and predicting social behaviour. Englewood Cliffs, NJ: Prentice Hall.

Bamberg, S., \& Schmidt, P. (2003). Incentives, morality, or habit? Predicting students' car use for university routes with the models of Ajzen, Schwartz, and Triandis. Environment and behavior, 35(2), 264-285.

Bandura, A. (1989). Human agency in social cognitive theory. American Psychologist, 44, 1175-1184.

Barr S., Gilg A. W., Ford N. J. (2001). A conceptual framework for understanding and analysing attitudes towards household-waste management. Environment and Planning A 33(11), 2025-2048.

Beck, L., and Ajzen, I. (1991). Predicting dishonest actions using the Theory of Planned Behaviour. Journal of Research in Personality, 25(3), 285-301.

Census and Statistics Department. (2011). The profile of Hong Kong population analysed by district council district 2010. Hong Kong Monthly Digest of Statistics.

Chen, M. F., and Tung, P. J. (2010). The moderating effect of perceived lack of facilities on consumers' recycling intention. Environment and Behaviour, 42(6), 824-844.

Cheung, S. F., Chan, D. K. S., and Wong, Z. S. Y. (1999). Reexamining the Theory of Planned Behaviour in understanding wastepaper recycling. Environment and Behaviour, 31, 587-611.

Chin, W. W. (1998a). Issues and opinion on structural equation modeling. MIS Quarterly, 22(1), 7-16.

Chin, W. W. (1998b). The partial least squares approach for structural equation modeling. In G. A. Marcoulides (Ed.), Modern methods for business research (pp. 295-336). Mahwah, NJ: Erlbaum.

Chung, S. S. (2010). Projecting municipal solid waste: The case of Hong Kong SAR. Resources, Conservation and Recycling, 54, 759-768.

Cohen, J. (1988). Statistical power analysis for the behavioral sciences (2nd ed.). Hillsdale: NJ: Lawrence Erlbaum Associates.

Davies, J., Foxall, G. R., and Pallister, J. (2002). Beyond the intention-behaviour mythology: an integrated model of recycling. Market Theory, 2(1), 29-113.

Davis, G., Phillips, P. S., Read, A. D., and Iida, Y. (2006). Demonstrating the need for the development of internal research capacity: understanding recycling participation using the Theory of Planned Behaviour in West Oxfordshire, UK. Resources, Conservation and Recycling, 46, 115-127. 
Domina, T., and Koch, K. (2002). Convenience and frequency of recycling: implications for including textiles in curbside recycling programs. Environment and Behaviour, 34, 216-38.

Environment Bureau. (2013). Hong Kong: Blueprint for Sustainable Use of Resources 2013-2022. Retrieved from: http://www.enb.gov.hk/en/files/WastePlan-E.pdf.

Environmental Bureau. (2012). Strengthening waste reduction: is waste charging and option?. Retrieved from http://www.epd.gov.hk/epd/msw_consult/document/english.html.

Environmental Protection Department. (2005). A policy framework for the management of municipal solid waste, 2005-2014. Retrieved from http://www.epd.gov.hk/epd/msw/index.html.

Environmental Protection Department. (2010). An overview on challenges for waste reduction and management in Hong Kong. Retrieved from http://www.epd.gov.hk/epd/english/environmentinhk/waste/waste_maincontent.html.

Fishbein, M., and Ajzen, I. (1975). Belief, attitude, intention, and behaviour: An introduction to theory and research. Reading, MA: Addison-Wesley.

Fiske, C. A., Luebbehusen, L. A., Miyazaki, A. D., \& Urbany, J. E. (1994). The relationship between knowledge and search: it depends. Advances in Consumer Research, 21, 43-43.

Fornell, C., and Cha, J. (1994). Partial least squares. In Bagozzi, R. P. (Ed.), Advanced methods of marketing research (pp. 52-78). Cambridge, MA: Basil Blackwell.

Fornell, C., and Larcker, D. F. (1981). Evaluating structural equation models with unobservable variables and measurement error. Journal of Marketing Research, 18(1), 39-47.

Ganesan, S., and Lau, S. S. Y. (2000). Urban challenges in Hong Kong: Future directions for design. Urban Design International, 5(1), 3-12.

Gardner, G., Stern, P. (2002). Environmental problems and human behaviour. Boston, MA: Pearson Custom Publishing.

Gefen, D., Straub, D. W., and Boudreau, M. C. (2000). Structural equation modeling and regression: Guidelines for research practice. Communications of the Association for Information System, 4(7), 1-79.

Geller, E. (2002). The challenge of increasing proenvironmental behaviour. In Bechtel, R., Churchman A. Handbook of environmental psychology. New York: Wiley.

Godin, G., Valois, P., Lepage, L., and Desharnais, R. (1992). Predictors of smoking behaviour: An application of Ajzen's Theory of Planned Behaviour. British Journal of Addiction, 87(9), 1335-1343.

Gonzalez-Torre, P. L., Adenso-Diaz, B., and Ruiz-Torres, A. (2003). Some comparative factors regarding recycling collection systems in regions of the USA and Europe. Journal of Environmental Management, 69, 129-38.

Guy, P. (2002). The changing nature of public administration: from easy answers to hard 
questions. Asian Journal of Public Administration, 24(2), 153-183.

Hair, J. F., Anderson, R. E., Tatham, R. L., and Black, W. C. (1998). Multivariate data analysis, 5th ed, Upper Saddle River: Prentice Hall.

Hair, J. F., Ringle, C. M., \& Sarstedt, M. (2011). PLS-SEM: Indeed a silver bullet. The Journal of Marketing Theory and Practice, 19(2), 139-152.

Heath, Y., and Gifford, R. (2002). Extending the Theory of Planned Behaviour: Predicting the use of public transportation. Journal of Applied Social Psychology, 32(10), 2154-2189.

Henseler, J., Sarstedt, M. (2013). Goodness-of-fit indices for partial least squares path modelling. Computational Statistics, 28(2), 565-580.

Hopper, J., and Nielsen, J. M. (1991). Recycling as altruistic behaviour: normative and behavioural strategies to expand participation in a community recycling program. Environment and Behaviour, 23, 195-220.

Hornik, J., Cherian, J., Madansky, M., and Narayana, C. (1995). Determinants of recycling behaviour: A synthesis of research results. Journal of Socio-Economics, 24, 105-27.

Information Services Department. (2010). Press release - LCQ18: The number and locations of 3-coloured waste separation bins. Retrieved from http://www.info.gov.hk/gia/general/201005/26/P201005260108.htm.

Information Services Department. (2012). Press release - LCQ20: Crowd control in MTR stations. $\quad$ Retrieved from http://www.info.gov.hk/gia/general/201205/09/P201205090211.htm.

Information Services Department. (2013). Press release - LCQ19: Three-colour waste $\begin{array}{llll}\text { separation } \quad \text { bins. } & \text { Retrieved }\end{array}$ http://www.info.gov.hk/gia/general/201302/27/P201302270298.htm.

Jakobssona, C., Fujii, S., Gärling, T. (2000). Determinants of private car users' acceptance of road pricing. Transport Policy, 7(2), 153-158.

Jöreskog, K. G. (1989). LISREL 7: A guide to the program and applications. Chicago: SPSS.

Jöreskog, K. G., and Wold, H. (1982). The ML and PLS techniques for modeling with latent variables: Historical and comparative aspects. In K. G. Jöreskog, and H. Wold (Eds.), Systems under indirect observation: Causality, structure and prediction (pp. 219-243). Amsterdam: North Holland.

Kelly, T. C., Mason, I. G., and Leiss, M. W. (2006). University community responses to on-campus resources recycling. Resources Conservation and Recycling, 47, 42-55.

Kingdon, J. (1995). Agendas, alternatives and public policies. NewYork: Longman.

Latan, H., and Ghozali, I. (2012). Partial Least Squares: Concept and Application Path Modeling using program XLSTAT-PLS for Empirical Research, BP UNDIP.

Legislative Council. (2013). Discussion papers for Public Works Subcommittee Meeting: Southeast New Territories Landfill Extension, Northeast New Territories Landfill Extension, and West New Territories Landfill Extension. 
MacKenzie, S. B., \& Spreng, R. A. (1992). How does motivation moderate the impact of central and peripheral processing on brand attitudes and intentions? Journal of Consumer Research, 519-529.

Mathieson, K. (1991). Predicting user intention: comparing the technology acceptance model with the Theory of Planned Behaviour. Information Systems Research, 2(3), 173-191.

May, P. (1986). Politics and policy analysis. Political Science Quarterly, 101(1), 109-125.

OECD (The Organisation for Economic Co-operation and Development). (2006). Background Document on Public Consultation.

Oom Do Valle, P., Rebelo, E., Reis, E., and Menezes, J. (2005). Combining behavioural theories to predict recycling involvement. Environment and Behaviour, 37(3), 364-396.

Oreg, S., and Katz-Gerro, T. (2006). Predicting proenvironmental behaviour cross-nationally: Values, the Theory of Planned Behaviour, and value-belief-norm theory. Environment and Behaviour, 38, 462-483.

Oskamp, S., Harrington, M. J., Edwards, T. C., Sherwood D. L., Okuda S. M., and Swanson, D. C. (1991). Factors influencing household recycling behaviour. Environment and Behaviour, 23, 494-519.

Parker, D., Manstead, A. S. R., Stradling, S. G., Reason, J. T., and Baxter, J. S. (1992). Intention to commit driving violations: An application of the Theory of Planned Behaviour. Journal of Applied Psychology, 77(1), 94-101.

Ringle, C.M., Wende, S., Will, S. (2005). SmartPLS 2.0 (M3) Beta, Hamburg, http://www.smartpls.de.

Saphores, J. M., Nixon, H., Ogunseitan, O. A., and Shapiro, A. A. (2006). Household willingness to recycle electronic waste: An application to California. Environment and Behaviour, 38, 183-208.

Schiffman, L. G., \& Kanuk, L. L. (2010). Consumer behaviour, 10th ed. New Jersey: Pearson Prentice Hall.

Schneider, A., Ingram, H. (1990). Behavioural Assumptions of Policy Tools. The Journal of Politics, 52(2), 510-529.

Schwartz, S. H. (1977). Normative influences on altruism. In L. Berkowitz (Ed.), Advances in experimental social psychology (pp. 221-279). New York: Academic Press.

Scott, I. (2000). The disarticulation of Hong Kong's post-handover political system. The China Journal, 43, 29-53.

Sidique, S. F., Lupi, F., and Joshi, S. V. (2010). The effects of behaviour and attitude on drop-off recycling activities. Resources, Conservation and Recycling, 54, 163-170.

Sing Tao Daily. (2013). Insufficient provision of waste separation bins. Retrieved from http://www.singtao.com.hk/yesterday/loc/0502ao08.html. [in Chinese].

Steg, L., Dreijerink, L., Abrahamse, W. (2006). Why are energy policies acceptable and effective? Environment and Behaviour, 38(1), 92-111. 
Steg, L., Dreijerink, L., and Abrahamse,W. (2005). Factors influencing the acceptability of energy policies: testing VBN theory. Journal of Environmental Psychology, 25(4), 415-425.

Steg, L., Vlek, C. (2009). Encouraging pro-environmental behaviour: An integrative review and research agenda. Journal of Environmental Psychology, 29(3), 309-317.

Stern, P. C., Dietz, T., and Guagnano, G. A. (1995). The New Ecological Paradigm in Social Psychology Context. Environment and Behaviour, 26, 723-743.

Tang, B., Wong, S., and Lee, A. K. (2007). Green belt in a compact city: A zone for conservation or transition? Landscape and Urban Planning, 79(3-4), 358-373.

Tenenhaus, M., Esposito Vinzi, V., Chatelin, Y.-M., and Lauro, C. (2005). PLS path modeling. Computational Statistics and Data Analysis, 48(1), 159-205.

Tobler, C., Visschers, V., Siegrist, M. (2012). Addressing climate change: Determinants of consumers' willingness to act and to support policy measures. Journal of Environmental Psychology, 32(3), 197-207.

Tonglet, M., Phillips, P. S., and Read, A. D. (2004). Using the Theory of Planned Behaviour to investigate the determinants of recycling behaviour: A case study from Brixworth, UK. Resources Conservation and Recycling, 41, 191-124.

Trafimow, D. (2000). Habit as both a direct cause of intention to use a condom and as a moderator of the attitude-intention and subjective norm-intention relations. Psychology and Health, 15(3), 383-393.

Vining, J., and Ebreo, A. (1990). What makes a recycler? A comparison of recyclers and non-recyclers. Environment and Behaviour, 22, 55-73.

Wan, C., Cheung R., Shen, G. (2012). Recycling attitude and behaviour in university campus: a case study in Hong Kong. Facilities, 30(13/14), 630-646.

Wan, C., Shen, G. (2013). Perceived policy effectiveness and recycling behaviour: The missing link. Waste Management, 33(4), 783-784.

Yiu, C.Y., Xu, S. (2012). A tenant-mix model for shopping malls. European Journal of Marketing, 46(3), 524-54. 


\section{Appendix A}

\begin{tabular}{|c|c|c|}
\hline \multirow{2}{*}{$\begin{array}{l}\text { Constructs } \\
\text { Attitude }\end{array}$} & \multicolumn{2}{|r|}{ Indicators } \\
\hline & ATTD1 & Recycling is good. \\
\hline \multirow[t]{5}{*}{ (ATTD) } & ATTD2 & Recycling is useful. \\
\hline & ATTD3 & Recycling is rewarding. \\
\hline & ATTD4 & Recycling is responsible. \\
\hline & ATTD5 & Recycling is sensible. \\
\hline & ATTD6 & Recycling is hygienic. \\
\hline \multirow{4}{*}{$\begin{array}{l}\text { Subjective Norm } \\
(\mathrm{SUBN})\end{array}$} & SUBN1 & Most people who are important to me think I should recycle. \\
\hline & SUBN2 & $\begin{array}{l}\text { Most people who are important to me would approve of my } \\
\text { recycling. }\end{array}$ \\
\hline & SUBN3 & My friends expect me to recycle household materials. \\
\hline & SUBN4 & My family expects me to recycle household materials. \\
\hline \multirow{7}{*}{$\begin{array}{l}\text { Perceived } \\
\text { Behavioural Control } \\
(\mathrm{PBC})\end{array}$} & PBC1 & I have plenty of opportunities to recycle. \\
\hline & $\mathrm{PBC} 2$ & Recycling is convenient. \\
\hline & PBC3 & Recycling is easy. \\
\hline & PBC4 & I know where to take my household waste for recycling. \\
\hline & PBC5 & I know how to recycle my household waste. \\
\hline & PBC6 & I have enough time to sort the materials for recycling. \\
\hline & PBC7 & I have enough space to store the materials for recycling. \\
\hline \multirow{5}{*}{$\begin{array}{l}\text { Moral Norm } \\
(\mathrm{MORN})\end{array}$} & MORN1 & I feel I should not waste anything if it could be used again. \\
\hline & MORN2 & It would be wrong of me not to recycle my household waste. \\
\hline & MORN3 & I would feel guilty if I did not recycle my household waste. \\
\hline & MORN4 & Not recycling goes against my principles. \\
\hline & MORN5 & $\begin{array}{l}\text { Everybody should share the responsibility to recycle household } \\
\text { waste. }\end{array}$ \\
\hline \multirow{5}{*}{$\begin{array}{l}\text { Consequences } \\
\text { Awareness } \\
(\mathrm{CONS})\end{array}$} & CONS1 & Recycling reduces pollution. \\
\hline & CONS2 & Recycling reduces wasteful use of landfills. \\
\hline & CONS3 & Recycling conserves natural resources. \\
\hline & CONS4 & Recycling improves environmental quality. \\
\hline & CONS5 & Recycling saves energy. \\
\hline \multirow{5}{*}{$\begin{array}{l}\text { Perceived Policy } \\
\text { Effectiveness } \\
\text { (POLICY) }\end{array}$} & POLICY1 & $\begin{array}{l}\text { The waste separation bins provided by the Government are sufficient } \\
\text { to facilitate recycling. }\end{array}$ \\
\hline & POLICY2 & The Government provides clear guidelines on recycling. \\
\hline & POLICY3 & $\begin{array}{l}\text { The Government's promotion clearly explains the benefits of } \\
\text { recycling. }\end{array}$ \\
\hline & POLICY4 & The Government's policy encourages me to recycle. \\
\hline & POLICY 5 & The Government's policy facilitates me to recycle. \\
\hline \multirow{3}{*}{$\begin{array}{l}\text { Behavioural Intention } \\
\text { (INT) }\end{array}$} & INT1 & I intend to recycle my recyclables in the next 4 weeks. \\
\hline & INT2 & I will recycle my recyclables every time I have it for disposal. \\
\hline & INT3 & I am willing to participate in the recycling scheme in the future. \\
\hline
\end{tabular}

